\title{
Records and Descriptions of Epitoniidae (Orthogastropoda: Epitonioidea) from the Deep Sea off Northeastern Brazil and a Checklist of Epitonium and Opalia from the Atlantic Coast of South America
}

\author{
Silvio F. B. Lima, ${ }^{1}$ Martin L. Christoffersen, ${ }^{1}$ José C. N. Barros, ${ }^{2}$ and Manuella Folly \\ ${ }^{1}$ Departamento de Sistemática e Ecologia, Universidade Federal da Paraíba (UFPB), 58059-900 João Pessoa, PB, Brazil \\ ${ }^{2}$ Laboratório de Malacologia, Departamento de Pesca e Aquicultura, Universidade Federal Rural de Pernambuco (UFRPE), \\ Avenida Dom Manuel de Medeiros S/N, Dois Irmãos, 52171-030 Recife, PE, Brazil \\ ${ }^{3}$ Departamento de Zoologia, Instituto de Biologia, Centro de Ciências da Saúde, \\ Universidade Federal do Rio de Janeiro (UFRJ), Ilha do Fundão, 21941-570 Rio de Janeiro, RJ, Brazil
}

Correspondence should be addressed to Silvio F. B. Lima, sfblima@yahoo.com.br

Received 23 August 2011; Revised 7 October 2011; Accepted 13 December 2011

Academic Editor: Roger P. Croll

Copyright (๑) 2012 Silvio F. B. Lima et al. This is an open access article distributed under the Creative Commons Attribution License, which permits unrestricted use, distribution, and reproduction in any medium, provided the original work is properly cited.

\begin{abstract}
A total of six genera and 10 species of marine gastropods belonging to the family Epitoniidae were collected from dredges of the continental slope off Brazil during the development of the REVIZEE (Live Resources of the Economic Exclusive Zone) Program. These species, referable to the genera Alora, Amaea, Cycloscala, Epitonium, Gregorioiscala, and Opalia, are reported from bathyal depths off northeastern Brazil. Alora sp., Gregorioiscala pimentai n. sp., and Opalia revizee n. sp. are species heretofore unknown to science. A list of the species of Epitonium and Opalia from the Atlantic coast of South America is presented based primarily on data from the literature. In addition, an overview of the biodiversity and distribution of the genera studied is presented for the Atlantic Ocean.
\end{abstract}

\section{Introduction}

Mollusks are a diverse and abundant group, although often inconspicuous in the reef ecosystem. Among gastropods, species of Architectonicidae Gray, 1840, Coralliophilidae Chenu, 1859, Epitoniidae S. S. Berry, 1910, Muricidae Rafinesque, 1815, Nystiellidae Clench and Turner, 1952, Olividae Latreille, 1825, and Ovulidae Fleming, 1822, are known to live on stony and soft corals, hydroids, hydrocorals, discophores, siphonophores, gorgonians, zoanthids, and sea anemones, feeding on living cnidarian tissues [1-5].

Epitoniidae is a cosmopolitan family of carnivorous marine gastropods [1, 6-9] that occurs on a variety of substrata from the intertidal to the abyssal region [1] and feed mainly on cnidarian anthozoans $[1-3,8-17]$. These gastropods may also be free-living micropredators $[1,14,16]$ feeding on invertebrates such as annelid worms and nemerteans [14].

The systematics of Epitoniidae remain poorly resolved mainly due to the scarce material collected from the deep sea, which is often represented by one or a few shells [6-9, $14,16,18]$. Watson [18] reported the first epitoniids for Brazil and Rios [19-22] expanded knowledge on this group in Brazilian waters. However, the alpha taxonomy remains underestimated, and there is fragmented knowledge on the family in the country [22-31].

Brazilian programs of environmental characterization have been very important in the sampling of benthic communities from the continental shelf and deep waters. For example, Miyaji [30] identified five genera and 16 species of Epitoniidae collected in southeastern and southern Brazil 
during the REVIZEE (Live Resources of the Exclusive Economic Zone) Program. Dr. R. S. Absalão (pers. comm., April 2011) studied new and little known deep-water Epitoniidae (700 to $1950 \mathrm{~m}$ ) from the Campos Basin off the state of Rio de Janeiro, Brazil. These studies demonstrate the insufficient understanding of the real diversity of Epitoniidae.

This paper presents gastropods of the family Epitoniidae collected from the continental slope off northeastern Brazil during the REVIZEE Program (2000-2001) and lists the species of the genera Epitonium Röding, 1798, and Opalia Adams and Adams, 1853, reported for the Atlantic coast of South America. A total of 10 species of Epitoniidae were dredged from bathyal depths. Most of the species studied herein are poorly known, have not previously been recorded for the region, or are previously unknown to science. In several cases, only one or a few specimens with damaged shells were collected, identified, and figured. The goal is to provide more alpha taxonomic knowledge on the diversity and geographic ranges of Epitoniidae fauna in Brazil. In addition, an overview of the biodiversity and distribution of the genera studied is presented for the Atlantic Ocean.

\section{Material and Methods}

This study is based on 13 empty shells collected through dredging in northeastern Brazil by the fishing vessel "Natureza" between depths of 375 and 720 meters. Generic and specific identification is based on comparisons with descriptions and illustrations $[6-9,16,32,33]$. A checklist of the species of the genera Epitonium (Table 1) and Opalia (Table 2) known from the Atlantic coast of South America and their geographic and bathymetric distribution is presented based on data from the literature $[7,9,16,22-24,30$ $32,34-41]$, species registered in the online World Register of Marine Species [42], and databases of western Atlantic marine Mollusca [43] and Conquiliologistas do Brasil [44].

The supraspecific taxonomy of Epitoniidae is poorly defined and often inconsistent based solely on shell morphology $[6,8,16]$. Thus, the decision was made to assign species only to the genus level until future-changes-based new evidence from anatomical studies complement the taxonomy. The limits of the subgenera (e.g., Epitonium and Opalia) have not been clearly defined $[6,16]$.

Each species was photographed under a ZEISS EVO 40 Scanning Electron Microscope at the Management of Biostratigraphy and Applied Paleoecology of the Petrobrás Research Center or under an FEI QUANTA 200F Scanning Electron Microscope at the Center for Technological Research of Northeastern Brazil.

\section{Results}

\subsection{Taxonomic Account.}

Epitoniidae Berry, 1910

Epitonium Röding, 1798.

Epitonium fractum Dall, 1927 (Figures 1(a)-1(c)).

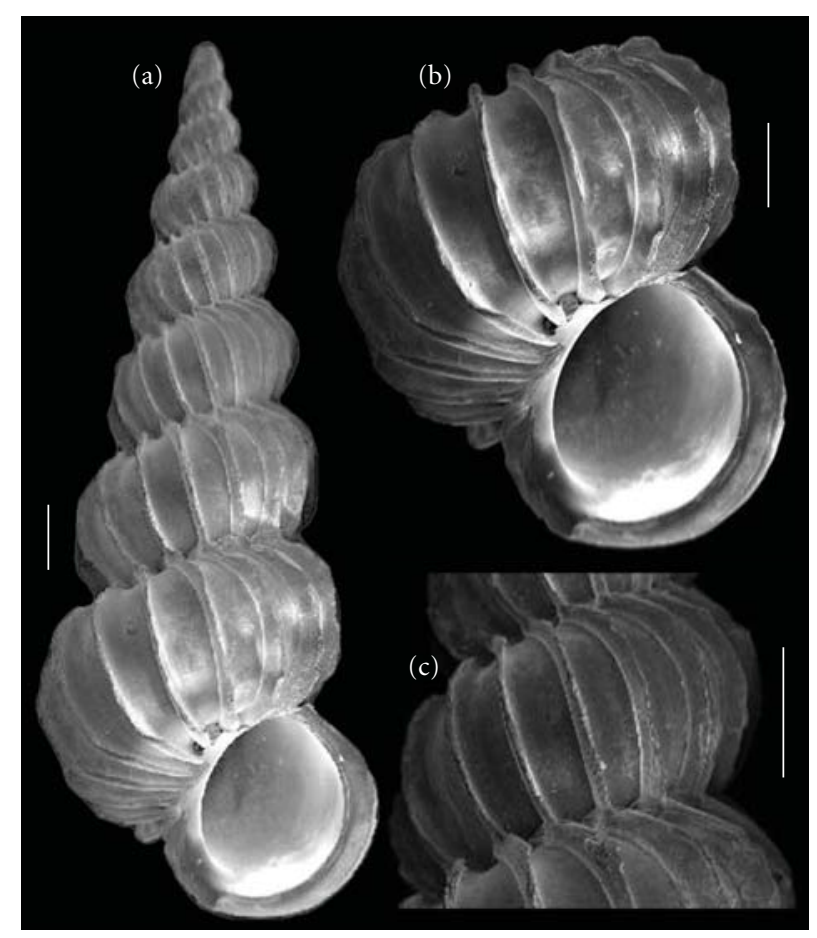

FIGURE 1: (a-c) Epitonium fractum (LMUFRPE); (a) ventral view, (b) view of last whorl, and (c) detail of teleoconch ornamentation. Scale bars: $(\mathrm{a}-\mathrm{c}) 500 \mu \mathrm{m}$.

Type Material and Locality. Holotype (USNM 108015, not examined)—off Fernandina, Florida [32].

Material Examined. 1 shell (LMUFRPE), Rio Grande do

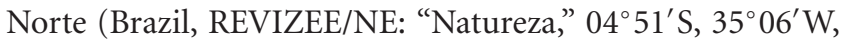
375 m, 24.xi.2001).

Characterization. Shell elongated, somewhat slender, strongly convex whorls attached by blade-like ribs with welldeveloped angles at shoulder (Figure 1(a)). Protoconch about 3.5 smooth whorls. Teleoconch with 8 to 16 whorls. About 17 to 20 axial ribs on last whorl. Spire extended (Figure 1(a)). Suture deep (Figures 1(a) and $1(c))$. Base sculptured with ribs with well-developed angulation (Figure 1(b)). Aperture subcircular, holostomatous (Figure 1(b)). Umbilicus minute, partially hidden by parietal lip and ribs (Figure 1(b)).

Geographic Distribution. Georgia [43], Florida [22, 32, 37, 45], Gulf of Mexico-off Louisiana [43], West Indies [22], Brazil: Rio Grande do Norte (present study), Espírito Santo [22] to São Paulo [30].

Remarks. The characters of the specimen examined here and those presented by Clench and Turner [32], Abbott [37], and Rios [22] fit the concept of Epitonium fractum (see original description in Dall [45]) and figure of type material in Clench and Turner [32]. This species has been collected on the continental shelf and slope $[22,32,37,45]$. It is similar 
Table 1: Checklist of species of the genus Epitonium known for the Atlantic coast of South America with geographic and bathymetric distribution.

\begin{tabular}{|c|c|c|}
\hline Species & Distribution (South America) & Depth $(\mathrm{m})$ \\
\hline (1) E. albidum (d’Orbigny, 1842) & Colombia, Venezuela, Brazil (CE, PE, AL, ES, RJ, SP, PR, SC), Uruguay & $0-366$ \\
\hline (2) E. angulatum (Say, 1831) & Colombia, Brazil (AP, CE, PE, AL, BA, ES, RJ, SP), Uruguay & $0-219$ \\
\hline (3) E. apiculatum (Dall, 1889) & Venezuela & $1-90$ \\
\hline (4) E. babylonia (Dall, 1889) & Colombia, Brazil (AP, CE, PE, SP) & $152-1337$ \\
\hline (5) E. candeanum (d’Orbigny, 1842) & $\begin{array}{l}\text { Colombia, Venezuela, Suriname, Brazil (AP, CE, PE, AL, SP), } \\
\text { Uruguay, Argentina }\end{array}$ & $0-805$ \\
\hline (6) E. cf. candeanum* & Brazil (PI) & $0-10$ \\
\hline (7) E. celesti (Aradas, 1854) & Brazil (RN, CE, RJ, SP, RS) & $146-640$ \\
\hline (8) E. cf. celesti & Brazil (RN) & 384 \\
\hline (9) E. dallianum (Verrill and Smith, 1880) & Brazil (ES, RS) & $90-478$ \\
\hline (10) E. denticulatum (Sowerby II, 1844) & Colombia, Venezuela, Brazil (AP, PA, CE, PE, AL, RJ) & $0-1472$ \\
\hline $\begin{array}{l}\text { (11) E. fabrizioi Pastorino and Penchaszadeh, } \\
\text { 1998* }\end{array}$ & Argentina & $0-2$ \\
\hline (12) E. foliaceicosta (d’Orbigny, 1842) & Colombia, Brazil (AL, BA, ES) & $0-219$ \\
\hline (13) E. fractum Dall, 1927 & Brazil (RN, ES, RJ, SP) & $64-594$ \\
\hline (14) E. frielei (Dall, 1889) & Brazil (AP, CE, RS) & $91-2941$ \\
\hline (15) E. georgettinum (Kiener, 1838)* & Brazil (BA, ES, SC, RS), Uruguay, Argentina & $0-101$ \\
\hline (16) E. hispidulum (Monterosato, 1874) & Brazil (RJ) & $750-800$ \\
\hline (17) E. humphreysii (Kiener, 1838) & Brazil (CE, PE, RS) & 0-95 \\
\hline (18) E. krebsii (Mörch, 1875) & Colombia, Venezuela, Brazil (AP, PA, CE, RN, PB, AL, SC) & $0-294$ \\
\hline (19) E. lamellosum (Lamarck, 1822) & Colombia, Venezuela, Brazil (ES) & $0-60$ \\
\hline (20) E. magellanicum (Philippi, 1845)* & Brazil (RS), Uruguay, Argentina, Chile & $0-545$ \\
\hline (21) E. matthewsae Clench and Turner, 1952 & Colombia & $11-219$ \\
\hline (22) E. multistriatum (Say, 1826) & Brazil (AL, RS) & $2.5-219$ \\
\hline (23) E. novangliae (Couthouy, 1838) & Colombia, Venezuela, Brazil (CE, PE, AL, ES, RJ, SC) & $0-457$ \\
\hline (24) E. occidentale (Nyst, 1871) & Venezuela, Brazil (CE, PE, AL, BA, RJ, SP) & $0-270$ \\
\hline (25) E. polacia (Dall, 1889) & Brazil (RJ) & $65-419$ \\
\hline (26) E. rupicola (Kurtz, 1860) & Colombia, Suriname (Holocene) & $0-65$ \\
\hline (27) E. sericifila (Dall, 1889) & Colombia & $0-7$ \\
\hline (28) E. striatissimum (Monterosato, 1878) & Argentina & $69-183$ \\
\hline (29) E. striatellum (Nyst, 1871)* & Brazil (SP, RS), Uruguay, Argentina & $10-70$ \\
\hline (30) E. cf. tiberii & Brazil (RN) & 384 \\
\hline (31) E. turritellulum (Mörch, 1875)* & Venezuela, Brazil (AP) & $6-40$ \\
\hline (32) E. unifasciatum (Sowerby II, 1844) & Colombia, Brazil (CE, PE, RS), Uruguay & $0-9$ \\
\hline (33) E. venosum (Sowerby II, 1844) & Venezuela & 61 \\
\hline (34) E. worsfoldi Robertson, 1994 & Brazil (ES) & 1 \\
\hline (35) E. xenicima (Melvill and Standen, 1903) & Colombia, Brazil (Bahia), Uruguay & $0-25$ \\
\hline
\end{tabular}

AP: Amapá, PI-Piauí, CE: Ceará, RN: Rio Grande do Norte, PB: Paraíba, PE: Pernambuco, AL: Alagoas, BA: Bahia, ES: Espírito Santo, RJ: Rio de Janeiro, SP: São Paulo, PR: Paraná, SC: Santa Catarina, RS: Rio Grande do Sul; $\left({ }^{*}\right)$ endemic to the Atlantic coast of South America.

to E. angulatum (Say, 1831), E. babylonia (Dall, 1889) and E. dallianum (Verrill and Smith, 1880) in the extended spire and shoulder angulation but differs from these species by the lack of spiral sculpture or spines on the shoulder (Figures 1(a)$1(\mathrm{c})$ ).

Epitonium cf. celesti (Aradas, 1854) (Figures 2(a)-2(c)).

Type Material and Locality. off Acitrezza (not examined), Sicily [16].
Material Examined. 1 shell (LMUFRPE), Rio Grande do Norte (Brazil, REVIZEE/NE: “Natureza”, 0451'40"S, $\left.35^{\circ} 08^{\prime} 01^{\prime \prime} \mathrm{W}, 384 \mathrm{~m}, 24 . x i .2001\right)$.

Characterization. Shell rather small, broad, slightly globose to turbinate (Figures 2(a) and 2(c)). Protoconch with about 4 whorls (Figure 2(b)). Teleoconch with about 3 almost disjunct whorls attached by blade-like, widely spaced ribs; ribs weakly recurved abaperturally at shoulder (Figures 2(a) and $2(\mathrm{c}))$. Microscopic sculpture consisting of numerous and 
TABle 2: Checklist of species of the genus Opalia known for the Atlantic coast of South America with geographic and bathymetric distribution.

\begin{tabular}{llc}
\hline Species & Distribution (South America) & Depth $(\mathrm{m})$ \\
\hline (1) O. abbotti Clench and Turner, 1952 & Brazil (PE, RJ, SP) & $64-704$ \\
(2) O. aurifila (Dall, 1889) & Brazil & $91-311$ \\
(3) O. burryi Voss, 1953 & Colombia & $30-168$ \\
(4) O. crenata (Linnaeus, 1758) & Venezuela, Brazil (AP, PA, AL to SC) & $0.3-82$ \\
(5) O. eolis Clench and Turner, 1950 & Brazil (RN), Southeastern Brazil & $60-384$ \\
(6) O. hotessieriana (d'Orbigny, 1842) & Brazil (AL to SC) \\
(7) O. cf. morchiana* & Southeastern Brazil \\
(8) O. pumilio (Mörch, 1875) & Brazil (AP, PI, CE, PE, AL) \\
(9) O. cf. pumilio* & Colombia & $0-165$ \\
(10) O. revizee n. sp.* & Brazil (AL) & -183 \\
\hline
\end{tabular}

AP: Amapá, PA: Pará, PI: Piauí, CE: Ceará, PE: Pernambuco, AL: Alagoas, RJ: Rio de Janeiro, SP: São Paulo, SC: Santa Catarina; (一) depth is not given by Miyaji [30]; $\left(^{*}\right)$ endemic to the Atlantic coast of South America.

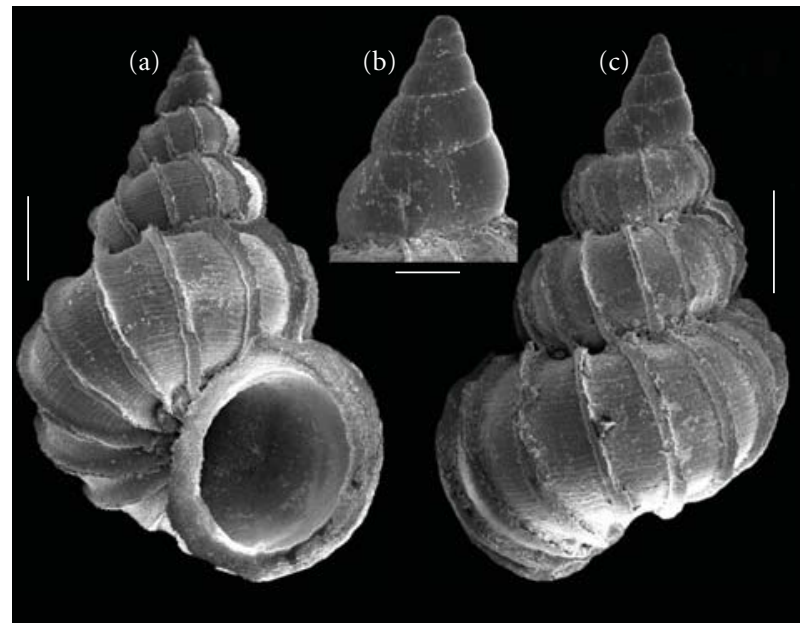

Figure 2: (a-c) Epitonium cf. celesti (LMUFRPE); (a) ventral view, (b) protoconch, and (c) dorsal view. Scale bars: (a) and (c) $500 \mu \mathrm{m}$, (b) $200 \mu \mathrm{m}$.

fine spiral threads (Figures 2(a) and 2(c)). Suture deep (Figure 2(c)). Base broad and rounded. Aperture oval, rather thickened and deflected. Umbilicus rather deep, narrow, sometimes slightly covered by reflection of lip, and/or thick extension of columella (Figure 2(a)).

Geographic Distribution. Eastern Atlantic-Mediterranean Sea, Portugal, Madeira, and Azores Islands [16, 22]; Western Atlantic-New Jersey [7, 16, 22], North Carolina, Florida, Bermuda, Bahamas Islands [7], Gulf of Mexico-Yucatan Strait [43], Cuba [7], Virgin Islands [7, 16, 22], Barbados [7], Brazil [21]: Rio Grande do Norte (present study); São Paulo [30]; Rio Grande do Sul [22].

Remarks. This species is similar to Epitonium krebsii (Mörch, 1875 ) in the globose-turbinate shell and blade-like ribs widely spaced and slightly abaperturally recurved at the shoulder but differs in that it has numerous fine spiral threads and does not have the wide umbilicus characteristic of E. krebsii. Clench and Turner [32], Abbott [37], and Rios [21] did not recognize any spiral sculpture on the teleoconch of E. krebsii.

The only specimen collected matches Epitonium celest $i$ in the conical protoconch with about 4 whorls as well as in the shell shape and in axial and spiral sculpture (see Bouchet and Warén [16]). The prominent axial ribs strongly recurved abaperturally at the shoulder forming a spine in Epitonium celest $i$ that seems to be somewhat different from the specimens illustrated herein. However, the only shell collected here is somewhat worn.

\section{Epitonium cf. tiberii (de Boury, 1890) (Figures 3(a)-3(c)).}

Material Examined. 1 shell (LMUFRPE), Rio Grande do Norte (Brazil, REVIZEE/NE: "Natureza," 0451'40"S, $\left.35^{\circ} 08^{\prime} 01^{\prime \prime} \mathrm{W}, 384 \mathrm{~m}, 24 . x i .2001\right)$.

Characterization. Shell conical-turbinate (Figure 3(a)). Protoconch conical, about 3.5 whorls, sculptured with subsutural spiral threads and opisthocline incremental lines (Figure 3(b)). Teleoconch about 3.5 whorls attached by prosocline blade-like ribs, slightly expanded, angulated, and with weak spine at shoulder (Figures 3(a) and 3(c)). Microscopic sculpture of numerous spiral threads (Figure 3(c)). First, second, and third teleoconch whorl sculptured with about 14, 18, and 22 axial ribs, respectively (Figure 3(a)). Suture deep and very constricted. Base conical, moderately elongated. Aperture oval. Outer and inner lip thin. Umbilicus minute, partially hidden by parietal lip and ribs (Figure 3(a)).

Geographic Distribution. Eastern Atlantic-Bay of Biscay to Cape Verde Islands [46]; western Atlantic_continental slope of Rio Grande do Norte (northeast Brazil: present study).

Remarks. Despite the wear, concretions on the surface of the teleoconch and the juvenile stage of the shell, this specimen approaches E. algerianum (Weinkauff, 1866), E. tiberii (de 


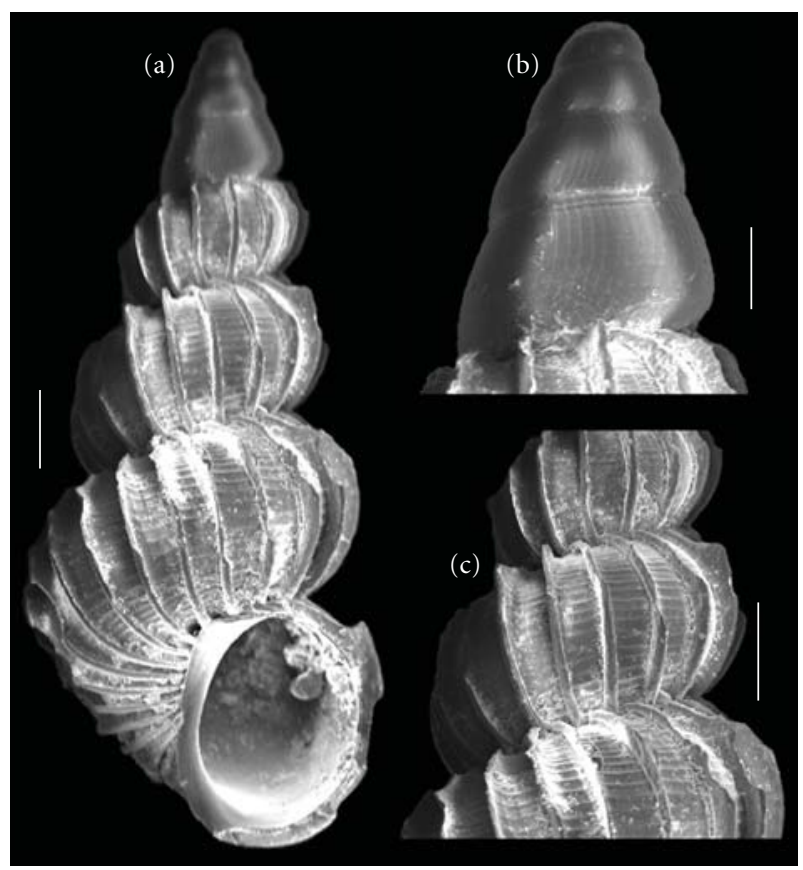

FIgURE 3: (a-c) Epitonium cf. tiberii (LMUFRPE); (a) ventral view, (b) protoconch and (c) detail of teleoconch ornamentation. Scale bars: (a) and (c) $500 \mu \mathrm{m}$, (b) $200 \mu \mathrm{m}$.

Boury, 1890), and E. tryoni (de Boury, 1913) (all from the eastern Atlantic) in shape and pattern of axial and spiral sculpture, including the slightly spinose projections at the shoulder. Epitonium algerianum has a robust shell and sinuous axial lamellae; E. tryoni has orthocline axial lamellae and an open umbilicus, while Epitonium cf. tiberii is characterized by a thin shell, prosocline axial ribs, and a minute umbilicus. Epitonium cf. tiberii approaches E. tiberii, although the protoconch of the present specimen is rather different from that shown by Bouchet and Warén [21] for E. tiberii. More material is necessary for further comparisons.

\section{Cycloscala Dall, 1889.}

Cycloscala echinaticosta (d'Orbigny, 1842) (Figures $4(\mathrm{a})-4(\mathrm{c}))$.

Type Material and Locality. Holotype (not examined)probably in NHMUK and St. Thomas-Virgin Islands [32].

Material Examined. 1 shell (MNRJ 17.165), Rio Grande do Norte (Brazil, REVIZEE/NE: “Natureza," 04 $51^{\prime} 40^{\prime \prime}$, $\left.35^{\circ} 08^{\prime} 01^{\prime \prime} \mathrm{W}, 384 \mathrm{~m}, 24 . x i .2001\right)$.

Characterization. Shell slightly globose to elongate-turbinate. Protoconch with 3.5 to 4 whorls. First postnuclear whorls attached and remaining disjunct or usually all disjunct whorls, sculptured with widely spaced axial ribs (Figure 4(a)). First postnuclear whorl narrowly coiled (Figure 4(a)). Second postnuclear whorl much more widely coiled (Figure 4(a)). First and second postnuclear whorls

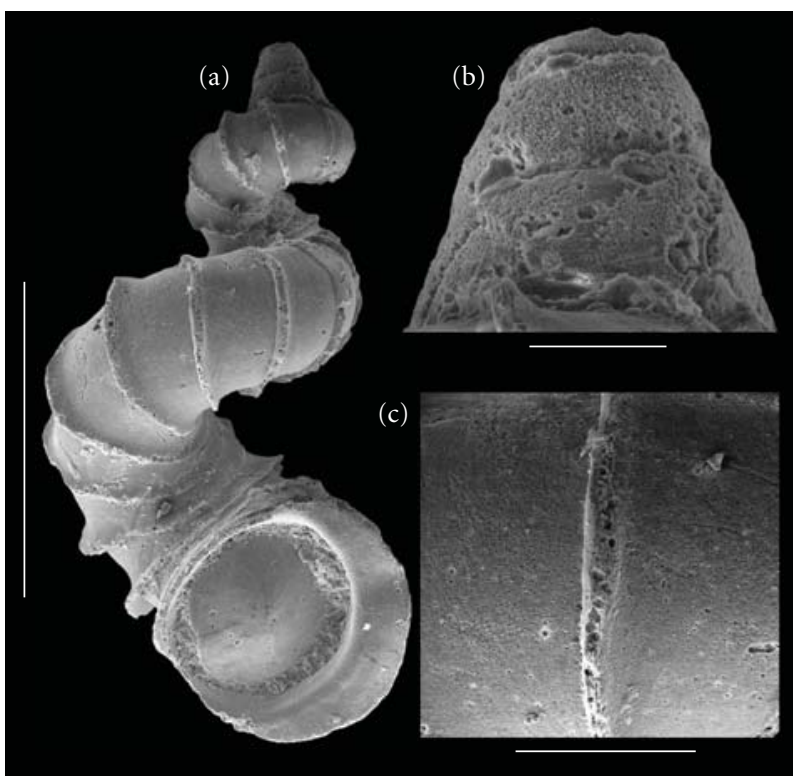

Figure 4: (a-c) Cycloscala echinaticosta (MNRJ 17.165); (a) ventral view, (b) protoconch view, and (c) detail of teleoconch ornamentation. Scale bars: (a) $1 \mathrm{~mm}$, (b) $100 \mu \mathrm{m}$, and (c) $200 \mu \mathrm{m}$.

with 8 to 9 scalloped axial costae completely encircling teleoconch (Figure 4(a)). Axial interspaces smooth (Figure 4(c)). Aperture circular (Figure 4(a)). Outer and inner lip thin (Figure 4(a)).

Geographic Distribution. North Carolina [43], Florida [22, 24, 32, 37], Bermuda [22, 24, 32, 33, 43, 47, 48], Bahamas [32, 33, 48, 49], Gulf of Mexico-off Louisiana [43], Belize [33], Costa Rica, Panama [43], Turks and Caicos, Cuba [32], Jamaica [32, 50], Haiti, Dominican Republic, Puerto Rico [43], Virgin Islands [32, 51-53], Anguilla [32], Barbados $[32,37]$, Bonaire [33, 54], Colombia [43], Brazil [22, 23, 37]: Pará [31], Rio Grande do Norte (present study), Fernando de Noronha Archipelago [22, 24, 48], Espírito Santo [43].

Remarks. Woodring [50] and Clench and Turner [32] classified this species as Epitonium (Cycloscala). Later, Kilburn [8] considered the subgenus to have characters sufficiently well defined to warrant full generic status. However, subsequent studies continued to recognize Epitonium echinaticosta [23, $24,31,48,49,54]$, except Garcia [33], who also discussed distinguishing characters in favor of treating Cycloscala on the generic level, mainly due to the disjunct postnuclear whorl, scalloped costae (Figure 4(a)), and shell body lacking spiral ornamentation (Figure 4(c)) $[8,33]$.

Currently, Cycloscala is a valid genus with about 13 species in the Pacific Ocean [46] and only Cycloscala echinaticosta in the Atlantic Ocean (between depths of 2 and $384 \mathrm{~m})[8,22,33,55]$. This taxon has considerable conchological variability $[32,33,48,49]$.

Amaea H. and A. Adams, 1853.

Amaea retifera (Dall, 1889) (Figures 5(a)-5(d)). 


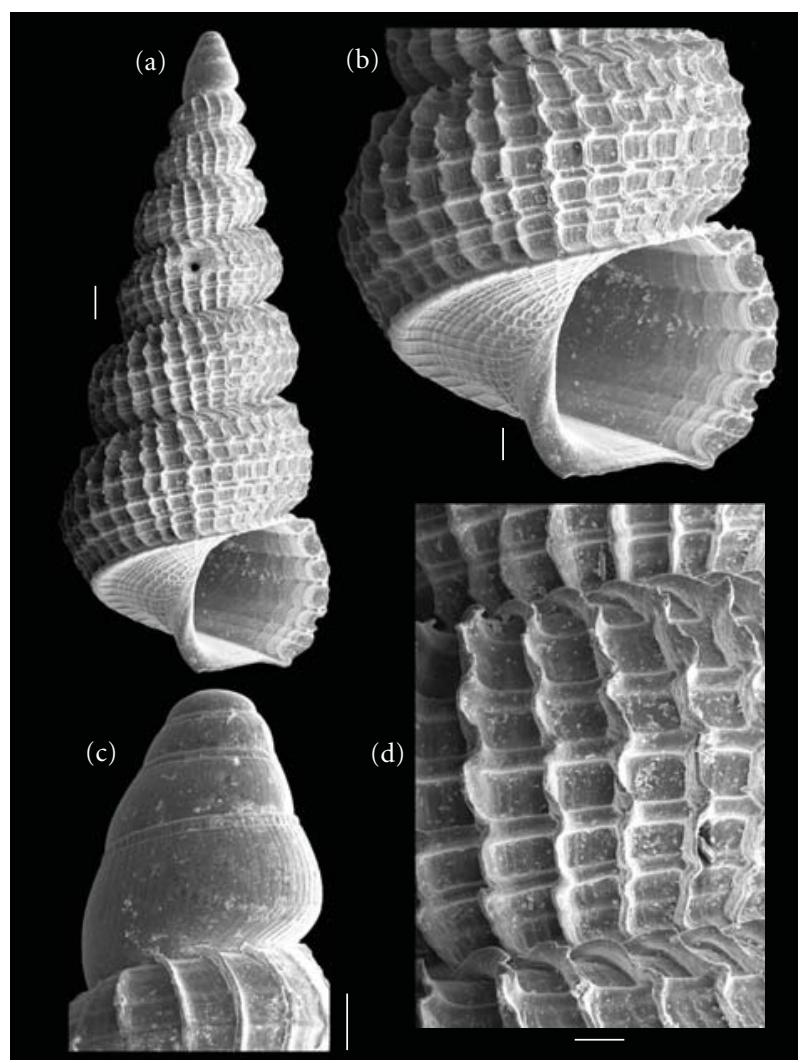

Figure 5: (a-d) Amaea retifera (LMUFRPE); (a) ventral view, (b) view of last whorl, (c) protoconch, and (d) detail of teleoconch ornamentation. Scale bars: (a), (b) and (d) $500 \mu \mathrm{m}$, (c) $100 \mu \mathrm{m}$.

Type Material and Locality. Holotype (USNM 83733, not examined)—off Cape Hatteras, North Carolina [6].

Material Examined. 1 shell (LMUFRPE)-Pernambuco (Brazil-REVIZEE/NE: “Natureza," $08^{\circ} 46^{\prime} 00^{\prime \prime} \mathrm{S}, \quad 34^{\circ} 44^{\prime}$ $00^{\prime \prime} \mathrm{W}, 690 \mathrm{~m}, 18 . x i .2000$ ).

Characterization. Shell turriform, elongate, thin. Teleoconch whorls with 6 to 16 whorls strongly convex, constricted (Figures 5(a) and 5(b)), sculptured with blade-like axial ribs (about 32 on last whorl) and spiral threads (7 to 8 on last whorl) with reticulated pattern (Figure 5(d)). Sculpture with rectangular intervals ornamented by axial striae (Figure 5(d)). Suture deep (Figures 5(a), 5(b) and 5(d)). Basal disc well developed, flat, sculptured with axial and spiral threads, delimited by prominent cord (Figure 5(b)). Base imperforate. Aperture oval (Figure 5(b)). Outer lip thickened (Figure 5(b)). Inner lip thin (Figure 5(b)).

Geographic Distribution. North Carolina [6, 37, 53, 56], Florida [6, 37, 56], Mexico [6, 56], Cuba, Puerto Rico [56], Anguilla, St. Barthelemy/St. Bartholomew, Antigua [43], Barbados [6, 56], Colombia, Venezuela, Surinam [43], Brazil [37]: Amapá, Pará [22, 31], and Pernambuco (present study).
Remarks. Amaea retifera and A. mitchelli Dall, 1896 are the only species reported for the western Atlantic [6, 22, 37, 39, 56, 57]. The conchological characters of Amaea retifera are unequivocal and differ from Amaea mitchelli by the presence of blade-like axial ribs and strongly convex, constricted whorls. Amaea retifera has been recorded by Rios [21, 22] and Oliveira and Rocha-Barreira [31] only in northern Brazil (Amapá and Pará).

\section{Alora H. Adams, 1861.}

$$
\text { Alora sp. (Figures 6(a)-6(f)). }
$$

Material Examined. 3 shells (MNRJ 17.166) and 2 shells (MZSP 101282)-Pernambuco (Brazil-REVIZEE/NE: "Natureza," $08^{\circ} 46^{\prime} 00^{\prime \prime}$ S, 34 $44^{\circ} 00^{\prime \prime} \mathrm{W}, 690 \mathrm{~m}$, 18.xi.2000).

Characterization. Shell thin, fragile, small, biconic, white (Figures 6(c) and 6(d)). Protoconch multispiral, conical, with 3.75 slightly convex whorls, sculptured with subsutural band, faint axial, and spiral striae (Figures 6(a) and 6(b)). Transition to teleoconch marked by straight axial edge and faint riblets (Figures 6(a) and 6(b)). Spire low, about 1/4 oftotal length (Figures 6(c) and 6(d)). Teleoconch with about 3 convex whorls; whorls rapidly increasing in diameter (Figures 6(c) and 6(e)), sculptured with closely spaced andfine axial incremental lines and raised spiral threads, rather irregularly disposed (Figure 6(f)); axial elements undulating as they cross spiral threads (Figure 6(f)). Suture rather deep (Figures 6(d) and 6(e)). Last whorl capacious, with strong peripheral carina, about $2 / 3$ of total length of shell (Figures 6(c)-6(e)); posterior half strongly convex, sculptured with about 15 spiral threads; base subtrigonal, delimited posteriorly by carina; 15 to 20 spiral threads below carina (Figures 6(c), 6(d) and 6(f)). Aperture large, rather ovate (Figure 6(c)). Parietal region straight (Figure 6(c)). Inner lip and columella straight (Figure 6(c)). Umbilicus enlarged, half-moon shaped (Figure 6(c)).

Geographic Distribution. Known from the continental slope off northeastern (Pernambuco: present study) and southeastern Brazil (Dr. R. S. Absalão—pers. comm., April 2011).

Remarks. Only two deep sea epitoniids of the genus Alora H. Adams, 1861, are described for the Atlantic Ocean: $A$. tenerrima (Dautzenberg and Fischer, 1896) and A. retifera Bouchet and Warén, 1986. Alora tenerrima is amphi-Atlantic (USA: Georgia and eastern Atlantic: Azores [16, 45]), while A. retifera is described for the northeastern Atlantic.

Alora sp. is an undescribed species from the Atlantic Ocean. Dr. R. S. Absalão (pers. comm., April 2011) identified this species for the Campos Basin (Brazil: Rio de Janeiro) based on dozens of specimens. A formal specific epithet is being provided by this researcher. Alora sp. and A. tenerrima are similar in the convexity of the teleoconch whorls (except for the last whorl), in the dominating spiral sculpture, in the shape of the aperture, parietal region, and straight inner lip, in the deep suture and in the enlarged umbilicus (half-moon 


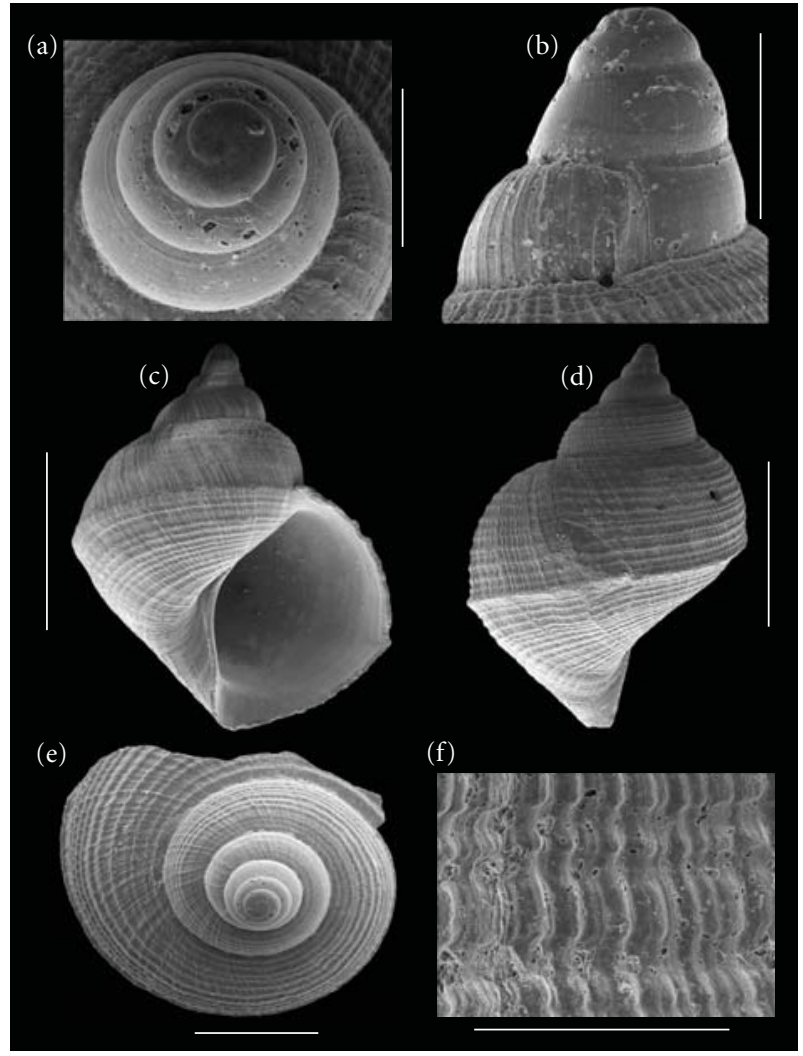

Figure 6: (a-f) Alora sp. (MNRJ 17.166); (a) and (b) protoconch view, (c) ventral view, (d) dorsal view, (e) apical view, and (f) detail of teleoconch ornamentation. Scale bars: (a) 200, (b) 300, (c) $1 \mathrm{~mm}$, (d) $2 \mathrm{~mm}$, (e) $500 \mu \mathrm{m}$, and (f) $400 \mu \mathrm{m}$.

shape). Alora sp. differs from A. tenerrima by the presence ofa peripheral carina, more numerous and weaker spiral threads, more closely spaced axial incremental lines, and a subtrigonal, not regularly convex last whorl. Alora tenerrima has about 5 spiral threads above the peripheral cord and 7 to 9 stronger threads below the cord; axial incremental lines are well spaced, and the last whorl is globose and regularly convex [16].

Opalia H. and A. Adams, 1853.

Opalia abbotti Clench and Turner, 1952 (Figures 7(a)-7(e)).

Type Material and Locality. Holotype (MCZ 184511, not examined) and off Puerto Tanamo, Cuba [7, 16].

Material Examined. 1 shell (IBUFRJ 18.828), Pernambuco (Brazil, REVIZEE/NE: “Natureza," $08^{\circ} 46^{\prime} 00^{\prime \prime} \mathrm{S}, 34^{\circ} 44^{\prime} 00^{\prime \prime} \mathrm{O}$, $690 \mathrm{~m}, 18 . x i .2000)$.

Characterization. Shell small, conical, whitish. Protoconch with 3.5 to 4 whorls sculptured with subsutural spiral band, slight axial threads, and microscopic pits (Figures 7(a) and 7 (b)). Teleoconch with 5 to 7 whorls, regularly convex, constricted, sculptured with strong, thick, high, rounded, widely

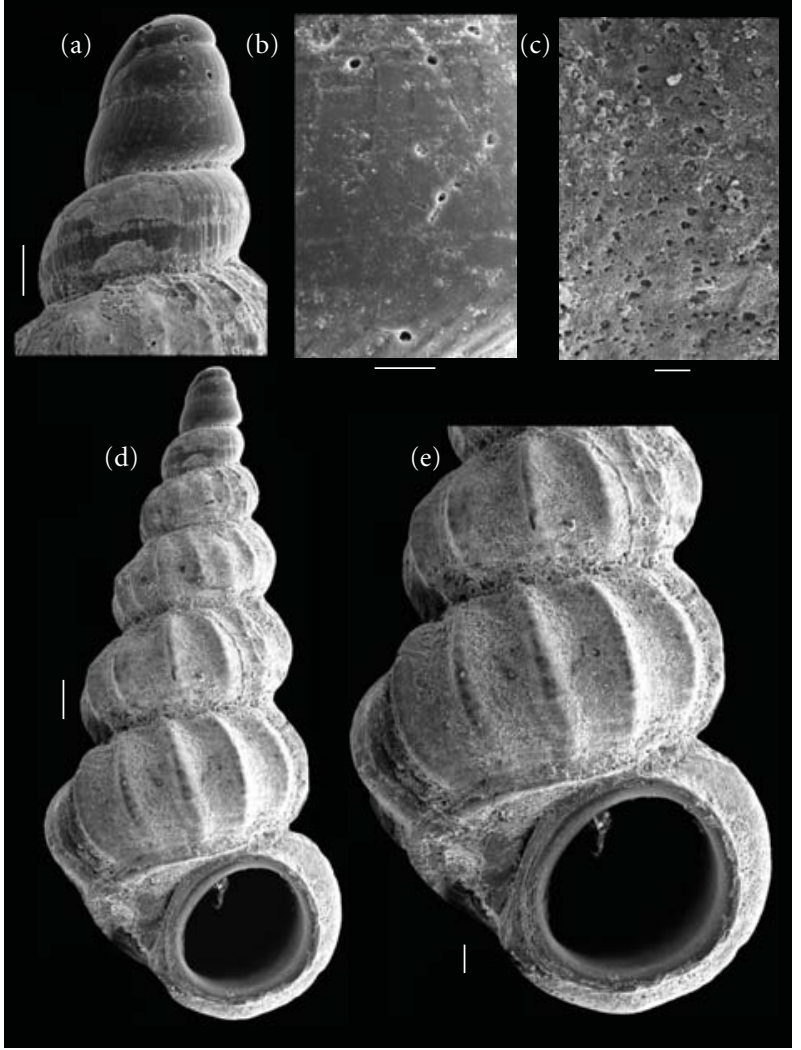

Figure 7: (a-e) Opalia abbotti (IBUFRJ 18.828); (a) protoconch, (b) detail of protoconch ornamentation, (c) detail of teleoconch ornamentation, (d) ventral view, and (e) view of last whorl and penultimate whorl. Scale bars: (a) $100 \mu \mathrm{m}$, (b) $20 \mu \mathrm{m}$, (c) $10 \mu \mathrm{m}$, (d) $200 \mu \mathrm{m}$, and (e) $100 \mu \mathrm{m}$.

spaced, and prosocline axial ribs (about 12 on last whorl) (Figures $7(\mathrm{~d})$ and $7(\mathrm{e})$ ) and numerous microscopic pits (Figure 7(c)). Basal disc delimited by prominent basal ridge (Figures 7(d) and 7(e)). Aperture circular (Figure 7(e)). Peristome thickened (Figure 7(e)). Umbilicus narrow and chinked (Figure 7(e)).

Geographic Distribution. Eastern Atlantic-northeastern Atlantic [16]; western Atlantic-Florida [7, 16, 37], Gulf of Mexico-off Louisiana [43], Cuba [16, 37, 56], Brazil: Pernambuco (present study) and São Paulo [30].

Remarks. This is an amphi-Atlantic species, but with extensive geographic distribution throughout the western Atlantic $[7,16,30,37,56]$. There are no previous records of Opalia abbotti for northeastern Brazil.

The only shell found here did not exhibit any morphological variation with respect to the specimens illustrated by Clench and Turner [7] and Bouchet and Warén [16]. According to Clench and Turner [7], the axial ribs on the last whorl in this species do not extend to the basal disc. However, these ribs may slightly invade the region (see Bouchet and Warén [16]).

Opalia eolis Clench and Turner, 1950 (Figures 8(a)-8(c)). 


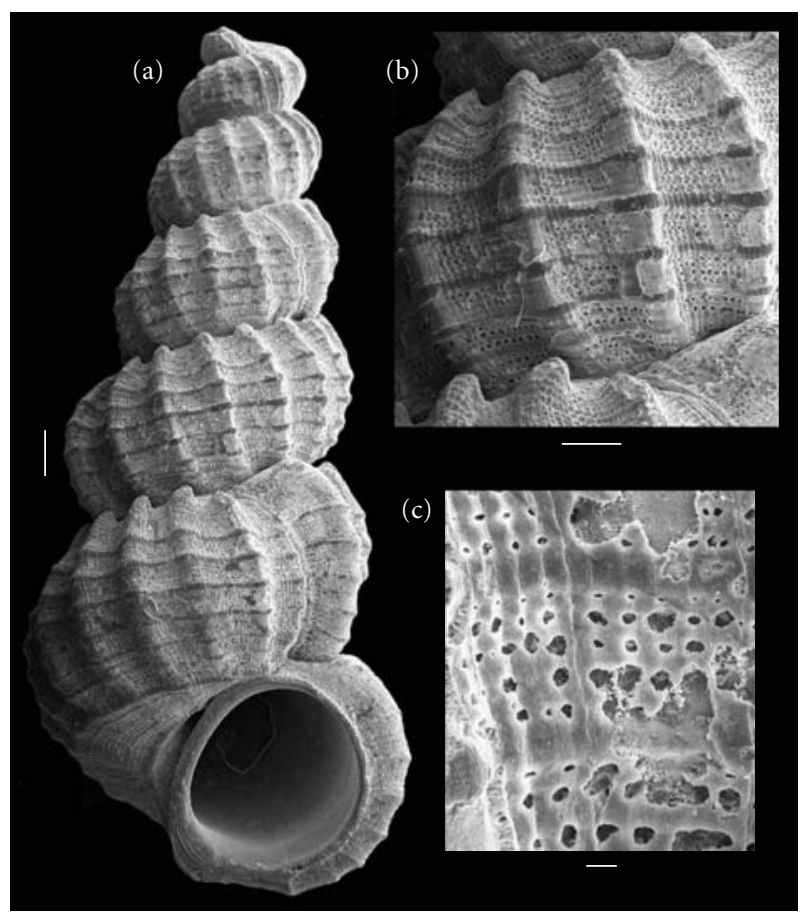

Figure 8: (a-c) Opalia eolis (MNRJ 17.170); (a) ventral view and (b), (c) detail of teleoconch ornamentation. Scale bars: (a) $500 \mu \mathrm{m}$ and (b), (c) $100 \mu \mathrm{m}$.

Type Material and Locality. Holotype (MCZ 187110, not examined) and off Looe Key, Lower Florida Keys, Florida (128 to $164 \mathrm{~m}$ ); paratypes (USNM, not examined) and off Fowey Light, Sand Key, and Palm Beach, Florida [6].

Material Examined. 1 shell (MNRJ 17.170), Rio Grande do Norte (Brazil, REVIZEE/NE: “Natureza," 04 51'40"S, $\left.35^{\circ} 08^{\prime} 01^{\prime \prime} \mathrm{W}, 384 \mathrm{~m}, 24 . x i .2001\right)$.

Characterization. Shell conical, elongate. Protoconch smooth, with 3 whorls. Teleoconch with 8 to 11 whorls regularly convex, rounded, constricted, sculptured with 16 to 20 strong, high, prosocline axial ribs, with crenulations at suture, 7 to 10 spiral threads, varix prosocline (Figures 8 (a) and $8(\mathrm{~b})$ ), surface covered by intritacalx sculptured with microscopic pits in oval pattern (Figure $8(\mathrm{c})$ ). Intersection of ribs and threads forming slight nodules (Figure $8(\mathrm{~b})$ ). Suture deeply impressed (Figure 8(b)). Basal disc delimited by slight spiral thread (Figure $8(\mathrm{a})$ ). Aperture subcircular (Figure 8(a)). Outer and inner lip thickened (Figure 8(a)). Umbilicus narrow and chinked (Figure 8(a)).

Geographic Distribution. Florida [6, 22], Mexico, Bahamas [49], Anguilla, Barbados [6, 22], Brazil: Rio Grande do Norte (present study), Rio de Janeiro [22], and São Paulo [30].

Remarks. This species is described in some studies as imperforate $[6,22]$. In some specimens, however, there is a small chink-like umbilicus [49]. Although not usually in

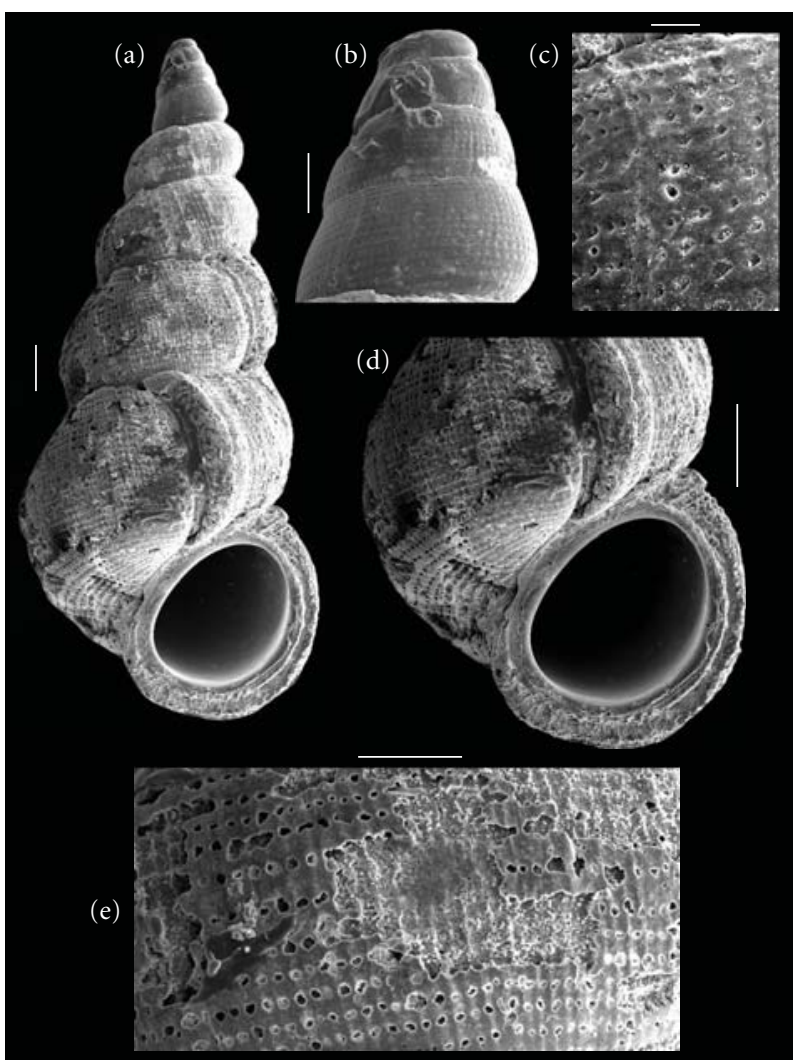

Figure 9: (a-e) Opalia revizee new species (holotype-MNRJ 18.307); (a) ventral view, (b) protoconch, (c) detail of protoconch ornamentation, (d) last whorl and aperture view, and (e) detail of teleoconch ornamentation. Scale bars: (a) $300 \mu \mathrm{m}$, (b) and (e) $100 \mu \mathrm{m}$, (c) $20 \mu \mathrm{m}$, and (d) $200 \mu \mathrm{m}$.

the description of this species, varices are seen in the images $[6,22]$.

Opalia revizee n. sp. (Figures 9(a)-9(e)).

Type Material. Holotype, 1 shell (MNRJ 18.307), Alagoas (Brazil, REVIZEE/NE: “Natureza," $10^{\circ} 06^{\prime} 35^{\prime \prime} \mathrm{S}, 35^{\circ} 46^{\prime} 41^{\prime \prime} \mathrm{W}$, $720 \mathrm{~m}, 16 . x i i .2001)$.

Description. Shell small, conical, whitish (Figure 9(a)). Protoconch conical, with 3 slightly convex whorls (Figure 9(b)), sculptured with spiral rows of microscopic pits (Figure 9(c)). Teleoconch with 5 rounded whorls, regularly convex (Figure 9(a)), surface covered by intritacalx densely sculptured with spiral rows of microscopic pits (Figure 9(e)). Varix prosocline and strong on penultimate whorl (Figures 9(a) and 9(d)). Suture well impressed (Figure 9(a)). Base weakly convex, without basal ridge, disc or umbilicus (Figure $9(\mathrm{~d})$ ). Aperture ovate (Figure 9(e)); peristome thickened, complete (Figure 9(e)).

Etymology. Named for the REVIZEE Program (Live Resources of the Exclusive Economic Zone). 
Type Locality. State of Alagoas ("Natureza," $10^{\circ} 06^{\prime} 35^{\prime \prime}$, $35^{\circ} 46^{\prime} 41^{\prime \prime} \mathrm{W}$ ) at a depth of 720 meters, muddy bottom, 16.xii.2001.

Geographic Distribution. Known only from the type locality.

Remarks. Opalia revizee new species is similar to and may be confused with O. eolis and O. fortunata Bouchet and Warén, 1986, due to the presence of a varix.

Opalia revizee and $O$. eolis are similar in the presence of a thickened outer lip, numerous microscopic pits, and a varix on the teleoconch. Opalia revizee is distinguished from $O$. eolis by the absence of a crenulated suture, spiral sculpture, axial threads, and ribs. Opalia eolis displays a crenulated suture, heavy axial ribs, and strong spiral cords $[6,37,49]$.

Opalia fortunata (northeastern Atlantic) is the species most closely related to $O$. revizee. Both have a similar outline of the shell, 3 whorls on the protoconch, about 5 whorls on the teleoconch, whorls regularly convex and sculptured with microscopic pits, a prosocline varix, a regularly convex base, a thickened and complete peristome, and the absence of a basal ridge or basal disk. Opalia revizee differs from $O$. fortunata by exhibiting an ovate aperture, surface covered with intritacalx densely sculptured with spiral rows of microscopic pits and no axial ribs or crenulated suture. Opalia fortunata has a rounded aperture, whorls covered by a smooth, finely pitted intritacalx, weak axial ribs, and suture weakly crenulated [16].

\section{Gregorioiscala Cossmann, 1912.}

Gregorioiscala pimentai n. sp. (Figures 10(a)-10(d)).

Type Material. Holotype, 1 shell (MNRJ 18.306), Alagoas (Brazil, REVIZEE/NE: "Natureza," $10^{\circ} 06^{\prime} 35^{\prime \prime} \mathrm{S}, 35^{\circ} 46^{\prime} 41^{\prime \prime} \mathrm{W}$, $720 \mathrm{~m}, 16 . x i i .2001)$.

Description. Shell whitish, small, strong, thick, conical (Figure 10(a)). Protoconch with about 2 moderately convex whorls, sculptured with microscopic pits (Figure 10(c)). Spire moderately high (Figure 10(a)). Suture moderately deep (Figures 10(a)-10(c)). Teleoconch with about 6 constricted whorls; whorls strongly convex, irregular in outline (Figure 10(a)); surface covered by intritacalx densely sculptured with microscopic pits in square pattern (Figure 10(b)). Axial sculpture with strong, thick, high, rounded, prosocline, widely spaced ribs that do not form crenulations in subsutural region (Figures 10(a) and 10(b)). Last whorl sculptured with 10 to 14 axial ribs, faint on basal ridge, weakly invading basal disc (Figure 10(d)). Base delimited posteriorly by prominent ridge keel (Figure $10(\mathrm{~d})$ ). Basal disc strongly flattened, large, sculptured with microscopic pits, weak ribs; prominent spiral rib at periphery of inner lip, with nodules in intersection of axial ornamentation (Figure 10(d)). Aperture rounded (Figures 10(a) and 10(d)); peristome thickened (Figure 10(d)); umbilicus very narrow and chinked (Figure 10(d)).

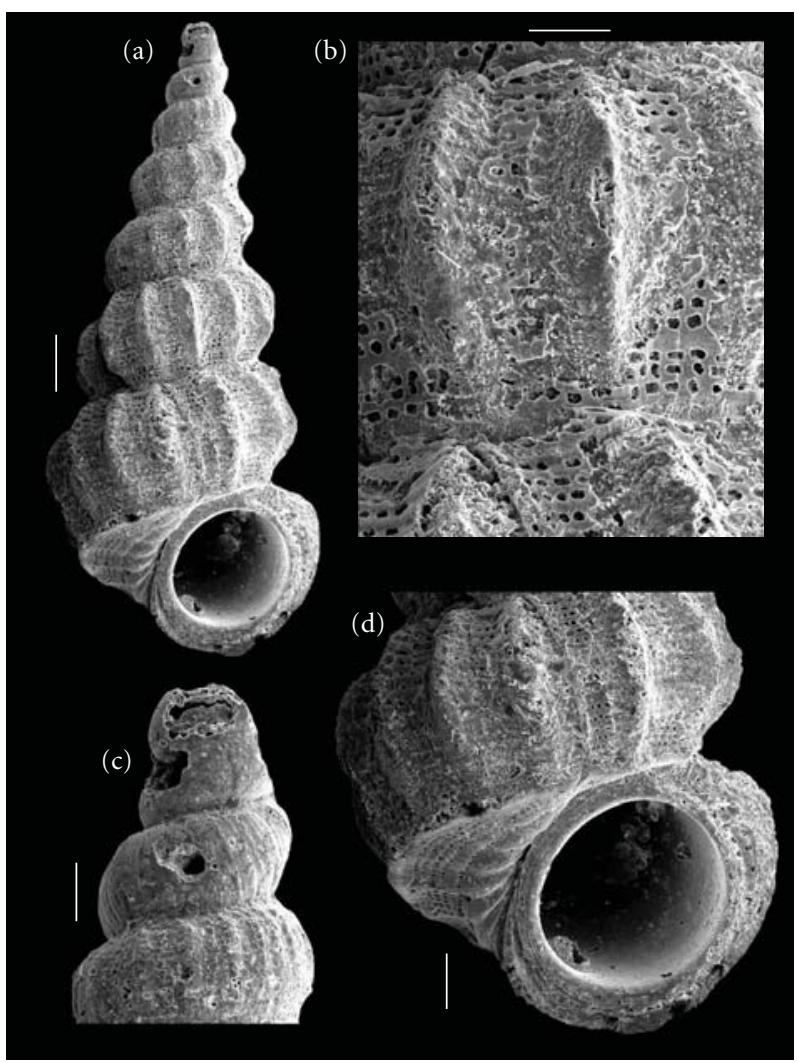

Figure 10: (a-d) Gregorioiscala pimentai new species (holotypeMNRJ 18.306); (a) ventral view, (b) detail of teleoconch ornamentation, (c) protoconch, and (d) view of last whorl. Scale bars: (a) $300 \mu \mathrm{m}$, (b), (c) $100 \mu \mathrm{m}$, and (d) $200 \mu \mathrm{m}$.

Etymology. In homage to Dr. Alexandre Dias Pimenta (MNRJ) for his initiative in reviewing the epitoniids and nystiellids of the Brazilian coast.

Type Locality. State of Alagoas ("Natureza," $10^{\circ} 06^{\prime} 35^{\prime \prime} \mathrm{S}$, $35^{\circ} 46^{\prime} 41^{\prime \prime} \mathrm{W}$ ), at a depth of 720 meters, muddy bottom, 16.xii.2001.

Geographic Distribution. Known only from the type locality.

Remarks. The taxon Gregorioiscala Cossmann, 1912, was erected to include deep-water epitoniid species with noncrenulated sutures, a relatively wide basal disk and a strongly defined basal ridge, thickened outer lip, thick pitted intritacalx, and strong axial ribs, some of which may form varices $[16,58]$. About 14 Gregorioiscala species are currently known in seas worldwide $[16,55,58]$. Gregorioiscala pachya (Locard, 1897 ) is the only deep sea congener reported for the western Atlantic (Gulf of Mexico) [55].

Gregorioiscala pimentai resembles G. pachya in presenting a teleoconch with constricted whorls; whorls irregular in outline; strong, thick, prosocline, widely spaced axial ribs, axial ribs of subsequent whorls not aligned in a row, suture 
moderately deep, and peristome thickened. Gregorioiscala pimentai is distinguished from G. pachya by the presence of a conical, less solid shell, teleoconch with 6 whorls, columellar axis not curved, teleoconch whorls not developing a shoulder, lacking varices, basal disc sculptured with weak axial ribs and a spiral rib present at the periphery of inner lip, forming nodules in the intersections with axial ribs. Gregorioiscala pachya is recognized by the turriculate, very solid, heavy shell, teleoconch with about 12 whorls, curved columellar axis, shouldered teleoconch whorls, some axial ribs forming varices and basal disc not sculptured with ribs [16].

\section{Discussion}

The present paper permits an extended analysis of the biodiversity and distribution of the genera studied in the Atlantic Ocean, with an emphasis on the taxa reported for South America. A review of the literature and together with the database offered by the present study resulted in records of three Alora, including A. sp. $[9,16]$, about four Amaea $[6,9$, 22, 57, 59], one Cycloscala [33, 49, 55], about four Gregorioiscala, including G. pimentai n. sp. [9, 16], fourteen Opalia, including $O$. revizee n. $\mathrm{sp}$. [6, 9, 16, 22, 37, 39, 42, 49], and about eighty Epitonium species [7, 9, 16, 22, 32, 37, 39, 42, $43,49,54]$ reported for the Atlantic Ocean. Information on the geographic and bathymetric distribution of Alora and Cycloscala was presented previously.

The genera Amaea and Gregorioiscala are among the most poorly represented epitoniids on both Atlantic coasts and species richness values therefore have little comparative meaning between regions. The two Amaea species from the western Atlantic are spread over a broad geographic area $[6,9,22,37,39,55,57]$, but only A. retifera has been recognized as significantly expanding the area of occurrence of the group to the Atlantic coast of South America and apparently beyond the continental shelf [22]. Other species have been found in the eastern Atlantic off West Africa $(A$. africana Bouchet and Tillier, 1978; A. guineensis Bouchet and Tillier, 1978) [9, 42, 59].

At least eleven Opalia species have been reported for the western Atlantic, five of which (O. crenata (Linnaeus, 1758), O. hotessieriana (d'Orbigny, 1842), O. pumilio (Mörch, 1875), O. eolis, and O. abbotti) have distributions shared between the Gulf of Mexico, West Indies, and the Atlantic coast of South America (Table 2) $[6,9,16,22,39,42,49$, $55]$, extending the southern limit of distribution (except $O$. pumilio) to southeastern/southern Brazil [22]. Opalia leeana (Verrill, 1882) and O. tortilis (Watson, 1883) are only known from their type localities [43]. This genus is still very poorly studied in the eastern Atlantic, with four species known for Europe $[9,16,42]$. Despite the occurrence of O. abbotti on both sides of the Atlantic $[7,16]$, there are wide gaps between the reported localities, especially between the West Indies and the northeastern portion of South America (see [7, 22, 37]). Most known species of Opalia in the Atlantic Ocean occur on the continental shelf $[6,7,9,22,37,39,49,56]$, with the exception of O. abbotti, O. aurifila (Dall, 1889), O. fortunata
Bouchet and Warén, 1986, O. leeana, O. tortilis, and O. revizee $\mathrm{n}$. sp., which have been recorded in deep waters (between depths of 200 and $713 \mathrm{~m}$ ) [6, 9, 16, 18, 22, 37, 53, $60]$.

The genus Epitonium has the highest number of described epitoniids $[7-9,11,14,22,23,32,37,39]$, with about forty species on both sides of the Atlantic [42, 43]. Currently, the Epitonium fauna of the western Atlantic may be divided into six categories on the basis of their distribution: (A) amphi-Atlantic species (4.79\%); (B) species widely distributed from the United States to the Caribbean Sea and the Atlantic coast of South America (38.09\%); (C) species distributed from the United States to the Caribbean Sea (16.66\%); (D) species known only for the coast of the United States (16.66\%); (E) species known only for the Caribbean Sea (11.90\%); (F) species restricted to the Atlantic coast of South America (11.90\%).

The data reviewed here reveal that Epitonium fauna with the greatest similarity occur between the Caribbean Sea and the Brazilian coast, as nearly half the species have records in both regions [7, 22, 32, 37, 41, 43, 49]. In the western Atlantic, about 20 species $(47.61 \%)$ are found at depths of less than $200 \mathrm{~m}$, while the other half has also been collected from deep waters [43]. In South America, the vertical range of Epitonium as a whole extends from the sublittoral zone (15 species; $42.8 \%$ ) to the bathyal zone (20 species; $57.2 \%$ ) (Table 1).

The only studies documenting Epitonium species in subregions of the Atlantic coast of South America were carried out by Diaz and Puyana [39] for Colombia (at least 16 species) and Rios [19-22] for Brazil. Not surprisingly, the Brazilian coast has the greatest richness of Epitonium in South America, with at least 25 species (Table 1) [22, 23, $31,32,37,41,44]$. However, this total is far from being considered satisfactory due to the vast areas with scarce or no information on Epitoniidae.

\section{Abbreviations}

IBUFRJ: Laboratório de Malacologia, Instituto de Biologia, Universidade Federal do Rio de Janeiro, Rio de Janeiro, Brazil;

LMUFRPE: Laboratório de Malacologia, Universidade Federal Rural de Pernambuco, Recife, Brazil;

MCZ: $\quad$ Museum of Comparative Zoology, Cambridge, USA;

MNRJ: $\quad$ Setor de Malacologia, Museu Nacional, Universidade Federal do Rio de Janeiro, Rio de Janeiro, Brazil;

MZSP: $\quad$ Museu de Zoologia, Universidade de São Paulo, São Paulo, Brazil;

NHMUK: The Natural History Museum, London, Great Britain;

SEM: $\quad$ Scanning Electronic Microscope;

USNM: National Museum of Natural History, Washington, USA. 


\section{Acknowledgments}

The authors are grateful to the Research and Management Center of Fishing Resources of the Northeastern CoastCEPENE/IBAMA for the collection of sediment and donation of material to the Malacology Laboratory of the Universidade Federal Rural de Pernambuco (UFRPE), Brazil; Dr. Fábio H. V. Hazin (DEPAq/UFRPE) for his constant support of our research; Drs. Emilio F. García (USA), R. N. Kilburn (Natal Museum, Pietermaritzburg), Alexandre D. Pimenta (MNRJ), Paulo M. S. Costa (MNRJ), Cristina A. Rocha-Barreira (Universidade Federal do Ceará), and M Sc Bruno G. Andrade (MNRJ) for their generous assistance in obtaining the literature; Drs. Priscila A. Grohmann (IBUFRJ), Carlos H. S. Caetano (Universidade Federal do Estado do Rio de Janeiro), and M Sc Raquel M. A. Figueira (IBUFRJ) for their suggestions for improving part of the study; Dr. Emilio F. García (USA) and M. Sc Bruno G. Andrade for their important contribution to the revision and corrections of the paper, confirmation of the identification of Epitoniidae, and for showing us the correct identification of Gregorioiscala; Dr. Roger P. Croll (Dalhousie University, Canada-Academic Editor of the International Journal of Zoology) and anonymous referees for their suggestions on the paper; Dr. Ricardo S. Absalão (IBUFRJ) for the supervision of the study of Manuella Folly; Mr. Richard Boike for the English revision of the paper.

\section{References}

[1] R. Robertson, "Wentletraps (Epitoniidae) feeding on sea anemones and corals," Proceedings of the Malacological Society of London, vol. 35, no. 2-3, pp. 51-63, 1963.

[2] R. Robertson, "Review of the predators and parasites of stony corals, with special reference to symbiotic prosobranch gastropods," Pacific Science, vol. 24, pp. 43-54, 1970.

[3] R. Robertson, "Epitonium millecostatum and Coralliophila clathrata: two prosobranch gastropods symbiotic with indopacific Palythoa (Coelenterata: Zoanthidae)," Pacific Science, vol. 34, no. 1, pp. 1-17, 1980.

[4] M. C. Hadfield, "Molluscs associated with living tropical corals," Micronesica, vol. 12, pp. 133-148, 1976.

[5] W. F. Ponder, D. J. Colgan, J. M. Healy, A. Nützel, L. R. L. Simone, and E. Strong, "Caenogastropoda," in Phylogeny and Evolution of the Mollusca, W. F. Ponder and D. R. Lindberg, Eds., University of California Press, Berkeley, Calif, USA, 2008.

[6] W. J. Clench and R. D. Turner, "The genera Sthenorytis, Cirsotrema, Acirsa, Opalia and Amaea in the Western Atlantic," Johnsonia, vol. 2, no. 29, pp. 221-246, 1950.

[7] W. J. Clench and R. D. Turner, "The genus Epitonium (Part II), Depressiscala, Cylindriscala, Nystiella and Solutiscala in the Western Atlantic," Johnsonia, vol. 2, no. 31, pp. 289-356, 1952.

[8] R. N. Kilburn, "The family Epitoniidae (Mollusca: Gastropoda) in southern Africa and Mozambique," Annals of the Natal Museum, vol. 27, pp. 239-337, 1985.

[9] A. Weil, L. Brown, and B. Neville, The Wentletrap Book: A Guide to the Tecent Epitoniidae of the World, Evolver, Rome, Italy, 1999.

[10] V. Fretter and A. Graham, British Prosobranch Molluscs, Ray Society, London, UK, 1962.
[11] V. Fretter and A. Graham, "The prosobranch molluscs of Britain and Denmark. Part 7. Heterogastropoda (Cerithiopsacea, Triphoracea, Epitoniacea, Eulimacea)," Journal of Molluscan Studies, supplement 11, pp. 363-434, 1982.

[12] H. F. Bosh, "A Gastropod parasite of solitary Corals in Hawaii," Pacific Science, vol. 19, no. 2, pp. 267-268, 1965.

[13] F. Perron, "The habitat and feeding behavior of the wentletrap Epitonium greenlandicum," Malacologia, vol. 17, no. 1, pp. 6372, 1978 .

[14] H. DuShane, "The family Epitoniidae (Mollusca: Gastropoda) in the northeastern Pacific," The Veliger, vol. 22, no. 2, pp. 91$134,1979$.

[15] H. Dushane, "Geographical distribution of some Epitoniidae (Mollusca: Gastropoda) associated with fungiid corals," The Nautilus, vol. 102, no. 1, pp. 30-35, 1988.

[16] P. Bouchet and A. Warén, "Revision of the Northeast Atlantic bathyal and abyssal Aclididae, Eulimidae, Epitoniidae (Mollusca, Gastropoda)," Bollettino Malacologico, supplement 2, pp. 299-576, 1986.

[17] B. Kokshoorn, "Epitoniid parasites (Gastropoda, Caenogastropoda, Epitoniidae) and their host sea anemones (Cnidaria, Actiniaria, Ceriantharia) in the Spermonde archipelago, Sulawesi, Indonesia," Basteria, vol. 71, pp. 33-56, 2007.

[18] R. B. Watson, "Report on the Scaphopoda and Gasteropoda collected by H.M.S. "Challenger" during the years 1873-1876," Reports on the Scientific Results of the Challenger Expedition, Zoology, vol. 42, pp. 1-756, 1886.

[19] E. C. Rios, Brazilian Marine Mollusks Iconography, Fundação Universidade do Rio Grande, Rio Grande, Brazil, 1975.

[20] E. C. Rios, Seashells of Brazil, Fundação Cidade do Rio Grande/ Museu Oceanográfico, Rio Grande, Brazil, 1985.

[21] E. C. Rios, Seashells of Brazil, Fundação Cidade do Rio Grande/ Museu Oceanográfico, Rio Grande, Brazil, 1994.

[22] E. C. Rios, Compendium of Brazilian Sea Shells, Evangraf, Rio Grande, Brazil, 2009.

[23] E. C. Rios and R. S. Absalão, "Contribución al conocimiento de la familia Epitoniidae S.S. Berry, 1910 en el Brasil," Comunicaciones de la Sociedad Malacologica del Uruguay, vol. 6, pp. 367-370, 1986.

[24] J. H. Leal, Marine Prosobranch Gastropods from Oceanic Islands off Brazil, Universal Books Services, Olgstgeet, The Netherlands, 1991.

[25] R. L. S. Mello, "Moluscos do Brasil. I. Gastropoda, Bivalvia e Scaphopoda, coletados durante as viagens do navio oceanográfico "Almirante Saldanha". Comissão Sul I. Considerações biogeográficas," Boletim do Museu de Malacologia da UFRPE, vol. 1, pp. 31-49, 1993.

[26] O. Tenório, J. C. N. Barros, and R. L. S. Mello, "Gastrópodes da Margem Leste e Sul não citados para o Brasil," Trabalhos Oceanográficos da Universidade Federal de PE, vol. 22, pp. 305323, 1993.

[27] J. C. N. Barros and E. A. Oliveira, "Comentários sobre três gastrópodes raros descritos por R. B. Watson, entre 1879 e 1885," Boletim do Museu de Malacologia, vol. 2, pp. 135-146, 1994.

[28] R. S. Absalão, A. D. Pimenta, and P. M. S. Costa, "Novas ocorrências de gastrópodes no litoral do Rio de Janeiro (Brasil)," Nerítica, vol. 10, pp. 57-68, 1996.

[29] J. C. N. Barros, F. N. Santos, M. C. F. Santos, E. Cabral, and F. D. Acioli, "Redescoberta de moluscos obtidos durante a "Challenger" Expedition (1873-1876): micromoluscos de águas profundas," Boletim Técnico-Científico do CEPENE, vol. 9, pp. 9-24, 2001. 
[30] C. Miyaji, "Classe gastropoda," in Biodiversidade Bentônica da Região Sudeste-Sul do Brasil-Plataforma Externa e Talude Superior, A. C. Z. Amaral and C. L. B. Rossi-Wongtschowski, Eds., Séries documentos Revizee: Score Sul, Instituto Oceanográfico, São Paulo, Brazil, 2004.

[31] F. M. R. Oliveira and C. A. Rocha-Barreira, "A família Epitoniidae (Mollusca: Gastropoda) do norte e nordeste do Brasil," Arquivos de Ciências do Mar, vol. 42, no. 1, pp. 121127, 2009.

[32] W. J. Clench and R. D. Turner, "The genus Epitonium in the Western Atlantic. Part I," Johnsonia, vol. 2, no. 30, pp. 249-288, 1951.

[33] E. F. Garcia, “On the genus Cycloscala Dall, 1889 (Gastropoda: Epitoniidae) in the Indo-Pacific, with comments on the type species, new records of known species, and the description of three new species," Novapex, vol. 5, no. 2-3, pp. 57-68, 2004.

[34] A. d'Orbigny, "Mollusques," Voyage dans l'Amérique Méridionale, vol. 5, pp. 59-69, 1839.

[35] P. Dautzenberg, "Croiseres du yatch "Chazalie" dans l' Atlantique, Mollusques," Mémoires de la Société Zoologique de France, vol. 13, pp. 145-265, 1900.

[36] B. Tursch and J. Pierret, "New species of mollusks from the coast of Brazil," The Veliger, vol. 7, pp. 35-37, 1964.

[37] R. T. Abbott, American Seashells, Van Nostrand Reinhold, New York, NY, USA, 2nd edition, 1974.

[38] C. O. van R. Altena, "The marine Mollusca of Suriname (Dutch Guiana), Holocene and recent III, Gastropoda and Cephalopoda," Zoologisches Verhandlinger, vol. 139, pp. 1-104, 1975.

[39] M. J. M. Diaz and H. M. Puyana, Moluscos del Caribe Colombiano, Colciencias, Fundación Natura Colômbia, Bogotá, Colombia, 1994.

[40] G. Pastorino and P. Penchaszadeh, "Epitonium fabrizioi (Gastropoda: Epitoniidae), a new species from Patagonia, Argentina," Nautilus, vol. 112, no. 2, pp. 63-68, 1998.

[41] B. G. Andrade, P. M. S. Costa, and A. D. Pimenta, "Revisão taxonômica do gênero Epitonium no Brasil (Gastropoda, Epitoniidae), exceto subgênero Asperiscala," in Proceedings of the Libro de Resumenes del 8th Congreso Latinoamericano de Malacología (CLAMA '11), G. Bigatti and S. V. Molen, Eds., Universidad Tecnológica Nacional, Universidad Nacional de la Patagonia San Juan Bosco, Buenos Aires, Agrnetina, Consejo Nacional Investigaciones Científicas Técnicas-CONICET, 2011.

[42] S. Gofas, Epitoniidae, World Register of Marine Species, 2011, http://www.marinespecies.org.

[43] G. Rosenberg, Malacolog 4.1.1: A database of western Atlantic marine Mollusca, 2009, http://www.malacolog.org/.

[44] Conquiliologistas do Brasil, 2011, http://www.conchasbrasil. org.br/.

[45] W. H. Dall, "Small shells from dredgings off the southeast coast of the United States by the United States Fisheries Steamer 'Albatross' in 1885 and 1886," Proceedings of the United States National Museum, vol. 70, pp. 1-134, 1927.

[46] S. Gofas, J. Le Renard, and P. Bouchet Mollusca, European Register of Marine Species: A Check-List of the Marine Species in Europe and a Bibliography of Guides to their Identification, vol. 50 of Collection Patrimoines Naturels, edited by M. J. Costello, C. S. Emblow and R. J. White, 2001.

[47] A. E. Verrill and K. J. Bush, "Additions to the marine Mollusca of the Bermudas," Transactions of the Connecticut Academy of Arts and Sciences, vol. 10, pp. 513-544, 1900.
[48] R. Robertson, "Protoconch size variation along depth gradients in a planktotrophic Epitonium," The Nautilus, vol. 107, no. 4, pp. 107-112, 1994.

[49] C. Redfern, Bahamian Seashells: A Thousand Species from Abaco, Bahamas, Bahamianseashells, Boca Raton, Fla, USA, 2001.

[50] W. P. Woodring, "Miocene Mollusks from Bowden, Jamaica. Part II. Gastropods and discussion of results," Carnegie Institute of Washington Publication, vol. 385, pp. 1-564, 1928.

[51] A. d'Orbigny, "Mollusques," Histoire Physique, Politique et Naturelle de lile de Cuba, vol. 2, pp. 1-112, 1842.

[52] O. A. L. Mörch, "Synopsis familiae Scalidarum Indiarum occidentalium. Oversigt over Vestindiens Scalarier," Videnskabelige Meddelelser fra den Naturhistoriske Forening i Kjöbenhavn, pp. 250-268, 1875.

[53] W. H. Dall, "Reports on the results of dredgings, under the supervision of Alexander Agassiz, in the Gulf of Mexico (187778 ) and in the Caribbean Sea (1879-80), by the U. S. Coast Survey Steamer 'Blake," Bulletin of the Museum of Comparative Zoology, vol. 18, pp. 1-492, 1889.

[54] K. M. De Jong and H. E. Coomans, Marine Gastropods from Curaçao, Aruba and Bonaire, E.J. Brill, Leiden, The Netherlands, 1988.

[55] G. Rosenberg, F. Moretzsohn, and E. F. García, "Gastropoda (Mollusca) of the Gulf of Mexico," in Gulf of Mexico-Origins, Waters, and Biota. Biodiversity, D. L. Felder and D. K. Camp, Eds., Texas A and M Press, College Station, Tex, USA, 2009.

[56] J. Espinosa and R. Fernández-Garcés, "La família Epitoniidae (Mollusca: Gastropoda) en Cuba," Poeyana, vol. 404, pp. 1-13, 1990.

[57] W. H. Dall, "On some new species of Scala," The Nautilus, vol. 9, pp. 111-112, 1896.

[58] E. F. Garcia, "New records of Opalia-like mollusks (Gastropoda: Epitoniidae) from the Indo-Pacific, with the description of fourteen new species," Novapex, vol. 5, no. 1, pp. 1-18, 2004.

[59] P. Bouchet and S. Tiller, "Two new giant Epitoniids (Mollusca: Gastropoda) from West Africa," The Veliger, vol. 20, no. 4, pp. 345-348, 1978.

[60] A. E. Verrill, "Catalogue of marine Mollusca added to the fauna of the New England region, during the past ten years," Transactions of the Connecticut Academy of Arts and Sciences, vol. 5, pp. 451-587, 1882. 

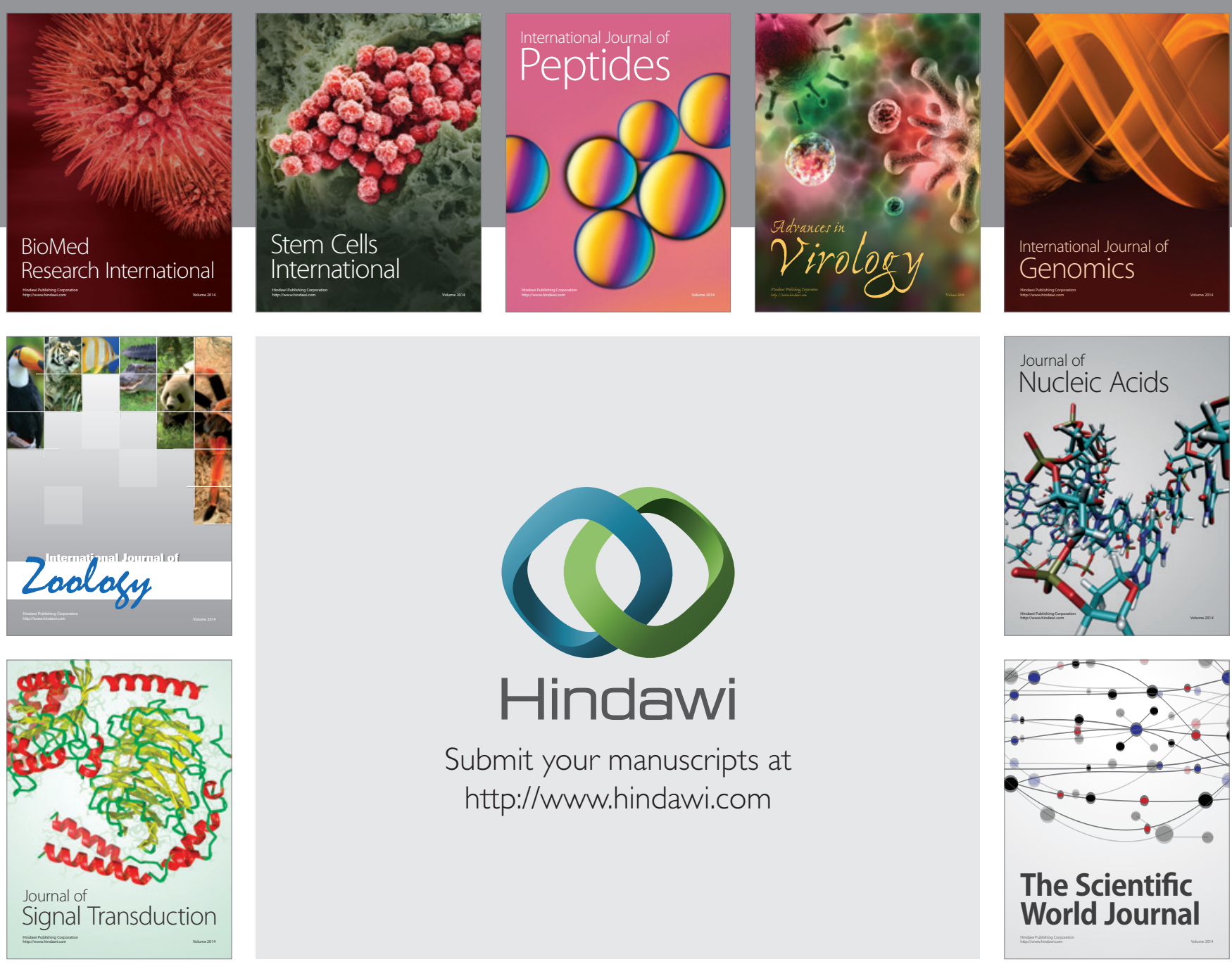

Submit your manuscripts at

http://www.hindawi.com
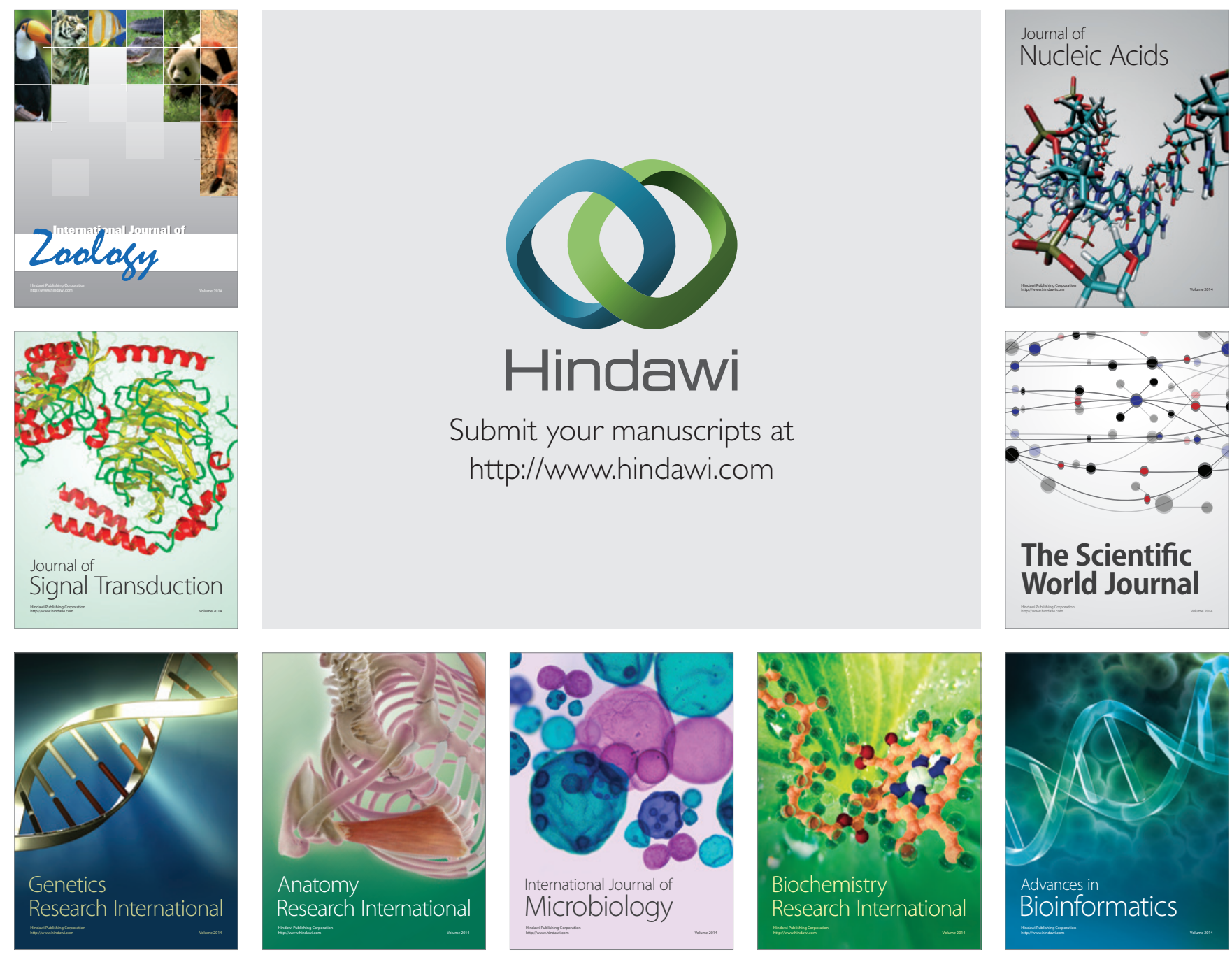

The Scientific World Journal
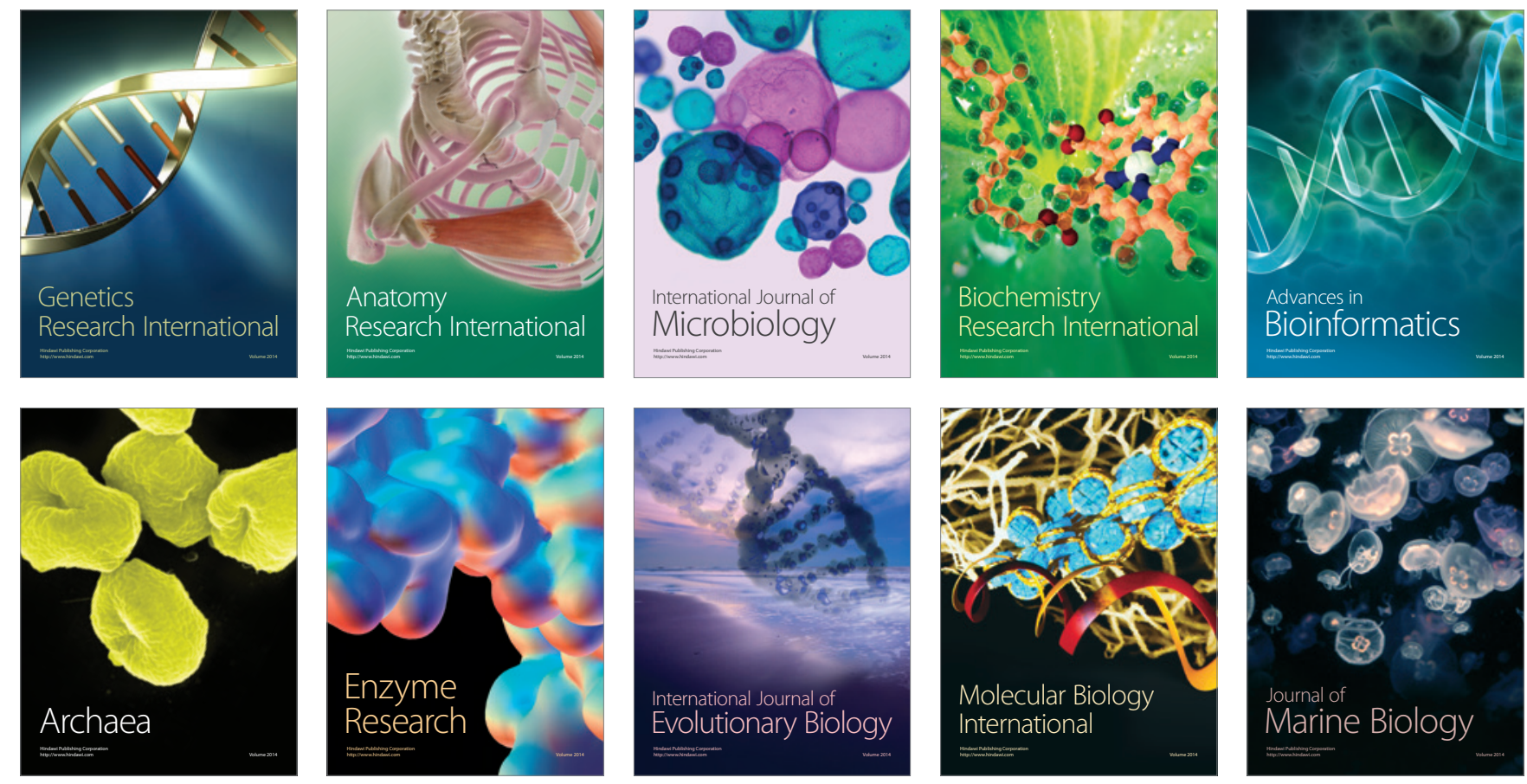